\title{
The genetic character of goats breed in Pomerania based on the polymorphism of blood proteins
}

\begin{abstract}
Summary
The experiment covered seven racial population of goats (740 females) breed in the region of Pomerania. Based on the electrophoresis of transferrin, hemoglobin, albumin and protein $\mathrm{X}$, it was established that there were two alleles in each locus, causing the presence of three genotypes. Observed distribution of those genotypes stayed in accordance with the expected one. Larger number of homozygous then heterozygous genotypes was observed among each studied population. The coefficient of mean heterozygosity was the lowest in Czech goats $(0.0655)$ while the highest was in Dutch White II (0.2938). Statistically significant differences were found in the frequency of alleles and genotypes, and in the level of homo- and heterozygosity in analyzed protein systems among all tested populations. Among studied goats populations, 18 hemotypes of 54 possible were present. According to hemotypes frequency, the level of genetic consolidation was established. The population of Dutch White Improved II appeared to be the most differentiated one while Czech White Improved - the most consolidated. The largest genetic distance was noted between Czech goats and Dutch White Improved II (0.03092). The smallest genetic distance characterized Saanen and Toggenburg goats (0.00200).
\end{abstract}

Key Words: Capra hircus, goats, polymorphism, albumin, hemoglobin, protein X, transferrin

\section{Zusammenfassung}

Titel der Arbeit: Genetische Charakteristik der in Pommern gezüchteten Ziegen auf Grund von Bluteiweißpolymorphismen

Untersucht wurden 740 Ziegen aus sieben in Westpommern gehaltenen Rassenpopulationen. Mittels Elektrophorese von Transferrin, Hämoglobin, Albumin und Eiweiß X wurde festgestellt, dass in jedem untersuchten locus je zwei Allele auftreten, welche die Anwesenheit von drei Genotypen anzeigen. Die festgestellte Verteilung stimmt mit dem Erwartungswert überein. In allen untersuchten Populationen waren die homozygoten Genotypen zahlenmäßig stärker vertreten. Die Frequenz der heterozygoten Genotypen war bei den Ziegen der tschechischen Rasse am niedrigsten (0,0655) und bei den Tieren der holländischen Population II am höchsten (0,2938). Ermittelt wurden sowohl die statistisch relevanten Unterschiede in der Frequenz von einzelnen Allelen und Genotypen als auch der Homo- und Heterozygotiegrad in den analysierten Eiweißstrukturen zwischen den untersuchten Rassen. In den analysierten Populationen traten insgesamt 18 Hämotypen von 54 möglichen auf. Wie bei den Frequenzen der Hämotypen wurde der Grad der genetischen Konsolidierung der Populationen bewertet. Die Ziegen der Rasse „Veredelte Holländische Weiße“ (Pop. II) waren genetisch am stärksten differenziert und die der Rasse „Veredelte Tschechische Weiße“ am wenigsten. Die größte genetische Distanz wurde zwischen Tieren der tschechischen Rasse und der holländischen Rassegruppe II (0,03092) festgestellt. Die geringste Distanz bestand zwischen Tieren der „Saanen Ziege“ und der „Toggenburger Ziege““(0,00200).

Schlüsselwörter: Ziegen, Polymorphie, Transferin, Hämoglobin, Albumin, Eiweiß X

\section{Introduction}

The importance of goat breeding has been increasing in Polish economic conditions. Goats are the animals extremely useful for breeding in middle and small individual farms, usually providing extensive farming. Unfortunately, the interest in goats breeding was decreasing in $1948-1970$. Total number of those animals was estimated 
at more than 800000 in 1948 and in 1970 it fold down to 40000 . Not earlier than in 80 's, goats came back to polish farming as an interesting species. The import of new material from foreign breeds has been observed. The breeders enlarge they herds not examining the pedigree and the quality of imported animals. In such situation, it is very important to provide genetic character of goats breed in Poland and to estimate the genetic distance between studied racial populations.

\section{Materials and Methods}

The experiment covered 740 goats came from the herds breed in Pomerania. There were seven racial populations (six imported ones and one native): 112 goats of Polish White Improved, 290 - Czech White Improved, 50 - Dutch White Improved I, 40 Dutch White Improved II, 160 - Saanen, 55 - Alpine and 33 - Toggenburg. Goats belonged to Dutch White Improved I an II were treated as different populations since they had come from different herds in Holland and were breed under different conditions in Poland.

The genetic polymorphism of transferrin, albumin and protein $\mathrm{X}$ was detected for each population, using the method of horizontal electrophoresis in starch gel by EFREMOV and BRAEND (1965) and hemoglobin by HUISMAN at al. (1958).

The results were statistically analyzed. Basing on the frequency of phenotypes, following values were calculated: the frequency of genotypes, alleles and the frequency of homo- and heterozygosity. According to the results obtained for each studied loci, the mean homo- and heterozygosity (KATSUMATA et al., 1981) and the frequency of each hemotype were estimated. The genetic distance between studied racial populations of goats was estimated basing on the NEI method [NEI, 1972; NEI and ROYCHOUDHURY, 1974].

The frequency of hemotypes was the base for estimating following values:

- level of genetic differentiation - number of animals in given population / number of hemotypes ratio $((\mathrm{N} / \mathrm{H})$

- index of the level of genetic differentiation - number of rare hemotypes / number of animals percentage ratio ( $\mathrm{h} / \mathrm{N}$ x $100 \%)$

- index of hemotypes differentiation - number of rare hemotypes / total number of hemotypes percentage ratio (h / H x 100\%) [KAMIŃSKI, 1982, 1984].

\section{Results and Discussion}

The presence of two alleles in each locus, which controlled three different genotypes, was establish basing on the results of electrophoretic separation of studied proteins.

For transferrin, the genotype AA appeared with the highest frequency: depending on the goat population it hesitated between 72.5 and $100.0 \%$. The genotype BB had the lowest frequency; it appeared only in some animals belonged to Polish White Improved and Dutch White Improved II (Table 1.). Another researchers obtained similar results of AA genotype frequency. However, in Italian Alpine goats, Hungarian Saanen (WATANABE et al., 1971), Barbari from India (BHAT et al., 1982), Alpine, Angora, Saanen from USA and Saanen from RPA (OSTERHOFF, 1995), the highest frequency was counted for heterozygotic genotype AB. Only Jumanapari goats in 
India were characterized by the highest frequency of BB genotype (BHAT et al., 1982).

Analyzing the polymorphism of hemoglobin, we observed the highest frequency for AA genotype $(60.0-98.3 \%)$ and the lowest one for BB $(0.0-5.0 \%)$ in each studied goat population. In Polish White Improved, Czech White Improved, Dutch White Improved I and Toggenburg, BB genotype was not present at all (Table 1.). Foreign researchers also noted the superior number of AA genotype. Some goat population, like Toggenburg (Germany), native Bulgarian (TJANKOV, 1972), Jumanapari (India) (BHAT et al., 1982) and Angora (RPA) (OSTERNHOFF, 1995) were monomorphic. They had only one hemoglobin genotype - AA. Only in Italian native goats Luciana (SALERNO, 1977) and Shinfield goats breed in United Kingdom (TRUCKER et al., 1983) the heterozygous genotype AB was observed.

Table 1

The frequency of transferrin, hemoglobin, albumin and protein $\mathrm{X}$ genotypes in studied populations of goats (Frequenz der Genotypen Transferrin, Hämglobin, Albumin und Eiwei $\beta$ X in den untersuchten Ziegenpopulationen)

\begin{tabular}{|c|c|c|c|c|c|c|c|}
\hline Genotype & $\begin{array}{l}\text { Polish White } \\
\qquad \begin{array}{c}n=112 \\
{[\%]}\end{array}\end{array}$ & $\begin{array}{l}\text { Czech White } \\
\qquad \begin{array}{c}n=290 \\
{[\%]}\end{array}\end{array}$ & $\begin{array}{c}\text { Dutch } \\
\text { White I } \\
\mathrm{n}=50 \\
{[\%]}\end{array}$ & $\begin{array}{c}\text { Dutch } \\
\text { White II } \\
\mathrm{n}=40 \\
{[\%]}\end{array}$ & $\begin{array}{c}\text { Saanen } \\
\begin{array}{c}n=160 \\
{[\%]}\end{array}\end{array}$ & $\begin{array}{c}\text { Alpine } \\
\mathrm{n}=55 \\
{[\%]}\end{array}$ & $\begin{array}{c}\text { Toggenburg } \\
\begin{array}{c}n=33 \\
{[\%]}\end{array}\end{array}$ \\
\hline $\begin{array}{l}\text { Tf AA } \\
\text { Tf AB } \\
\text { Tf BB }\end{array}$ & $\begin{array}{c}76.8^{\mathrm{ABC}} \\
21.4^{\mathrm{ADE}} \\
1.8\end{array}$ & $\begin{array}{c}96.6^{\mathrm{ADE}} \\
3.4^{\mathrm{ABC}} \\
0.0\end{array}$ & $\begin{array}{c}86.0^{\mathrm{BH}} \\
14.0^{\mathrm{BHI}} \\
0.0\end{array}$ & $\begin{array}{c}72.5^{\mathrm{aCFG}} \\
25.0^{\mathrm{CFG}} \\
2.5\end{array}$ & $\begin{array}{c}95.0^{\mathrm{DF}} \\
5.0^{\mathrm{DF}} \\
0.0\end{array}$ & $\begin{array}{c}100.0^{\mathrm{EGH}} \\
0,0^{\mathrm{EGHI}} \\
0.0\end{array}$ & $\begin{array}{c}90.9^{\mathrm{a}} \\
9.1 \\
0.0\end{array}$ \\
\hline $\begin{array}{l}\mathrm{Hb} \text { AA } \\
\mathrm{Hb} \text { AB } \\
\mathrm{Hb} \mathrm{BB}\end{array}$ & $\begin{array}{c}93.8^{\text {FGHIJKa }} \\
6.3^{\text {FGHIJ }} \\
0.0\end{array}$ & $\begin{array}{c}98.3^{\mathrm{ABCDEa}} \\
1.7^{\mathrm{ABCDE}} \\
0.0^{\mathrm{Aa}}\end{array}$ & $\begin{array}{c}78.0^{\mathrm{Afb}} \\
22.0^{\mathrm{AF}} \\
0.0^{\mathrm{B}}\end{array}$ & $\begin{array}{c}60.0^{\mathrm{BGHc}} \\
35.0^{\mathrm{Bga}} \\
5.0^{\mathrm{A}}\end{array}$ & $\begin{array}{c}77.5^{\mathrm{CILc}} \\
20.0^{\mathrm{EHKa}} \\
2.5^{\mathrm{ab}}\end{array}$ & $\begin{array}{c}60.0^{\mathrm{DJLb}} \\
38.2^{\mathrm{DIK}} \\
1.8^{\mathrm{Bb}}\end{array}$ & $\begin{array}{c}72.7^{\mathrm{EK}} \\
27.3^{\mathrm{CJ}} \\
0.0\end{array}$ \\
\hline $\begin{array}{l}\text { Alb FF } \\
\text { Alb FS } \\
\text { Alb SS }\end{array}$ & $\begin{array}{c}8.9^{\mathrm{A}} \\
13.4^{\mathrm{A}} \\
77.7^{\mathrm{Aab}}\end{array}$ & $\begin{array}{c}0.3^{\mathrm{ABCDE}} \\
2.4^{\mathrm{ABCDa}} \\
97.2^{\mathrm{ABCDE}}\end{array}$ & $\begin{array}{c}2.0 \\
6.0^{\mathrm{b}} \\
92.0^{\text {acde }}\end{array}$ & $\begin{array}{l}15.0^{\mathrm{B}} \\
17.5^{\mathrm{B}} \\
67.5^{\mathrm{Bc}}\end{array}$ & $\begin{array}{l}12.5^{\mathrm{C}} \\
21.3^{\mathrm{Cb}} \\
66.3^{\mathrm{Cbd}}\end{array}$ & $\begin{array}{c}7.3^{\mathrm{D}} \\
12.7^{\mathrm{D}} \\
80.0^{\mathrm{D}}\end{array}$ & $\begin{array}{c}15.2^{\mathrm{E}} \\
12.1^{\mathrm{a}} \\
72.7^{\mathrm{Ee}}\end{array}$ \\
\hline 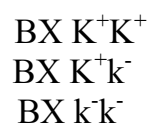 & $\begin{array}{c}62.5^{\mathrm{AFG}} \\
33.0^{\mathrm{AEF}} \\
4.5\end{array}$ & $\begin{array}{c}80.3^{\mathrm{ABCDE}} \\
18.6^{\mathrm{ABCDL}} \\
1.0^{\mathrm{AB}}\end{array}$ & $\begin{array}{c}64.0^{\mathrm{BHI}} \\
32.0^{\mathrm{GL}} \\
4.0\end{array}$ & $\begin{array}{c}52.5^{\mathrm{CJK}} \\
40.0^{\mathrm{BHI}} \\
7.5^{\mathrm{AC}}\end{array}$ & $\begin{array}{c}85.0^{\text {FHJLa }} \\
14.4^{\text {EGHJa }} \\
0.6^{\mathrm{CD}}\end{array}$ & $\begin{array}{c}52.7^{\mathrm{DLL}} \\
40.0^{\mathrm{CJK}} \\
7.3^{\mathrm{BD}}\end{array}$ & $\begin{array}{c}100.0^{\text {EGIKŁa }} \\
0.0^{\text {DFGIKa }} \\
0.0\end{array}$ \\
\hline
\end{tabular}

The frequencies, showed in lines marked with identical letter, differ significantly. Small letters indicate the significance of differences at $\mathrm{P} \leq 0.05$; big letters - at $\mathrm{P} \leq 0.01$

Albumin genotype SS was noted with the highest frequency in each examined population. Depending on population, it had a value of $66.3-97.2 \%$. Clearly lower frequency was observed for FS genotype $(2.4-21.3 \%)$ and the lowest one for FF genotype $(0.3-15.2 \%)$. Similar distribution of albumin genotypes was established by another researchers (WATANABE, 1971; TJANKOV, 1972; BARBANCHO et al., 1980; RODERO et al., 1997) in many different racial populations of goats (Table 4). Monomorphic type of albumin, which was present in one genetic variant SS, was detected in Swiss Saanen goats (WATANABE, 1971), Chinese goats (LIN et al., 1997), Japan Saanen, (NOZAWA et al., 1978, 1994) and in many goats population from different regions (PEPIN and NGUYEN, 1994; OSTERHOFF, 1995). The predominance of heterozygotic albumin genotype FS was found in native Italian population of Luciana goats (SALERNO, 1977) and in Spanish Murciana 
(BARBANCHO et al., 1980), while Saanen goats from Italy and Hungary, native Japan goats (WATANABE, 1971) and Serrana Andaluza from Spain were more homozygotic, with FF genotype.

Similar to another analyzed polymorphic blood proteins, the frequency of protein $\mathrm{X}$ genotypes was estimated according to Hardy-Weinberg law and the higher frequency was found for genotype $\mathrm{K}^{+} \mathrm{K}^{+}$. Depending on racial population it hesitated from 52.5 to $100.0 \%$ (Table 1.). Significantly lower frequency characterized genotype $\mathrm{K}^{+} \mathrm{k}^{-}(0.0-$ $40.0 \%)$ and the lowest one - recessive homozygotic genotype $\mathrm{k}^{-} \mathrm{k}^{-}(0.0-7.5 \%)$. Above results stay in accordance to those obtained for protein $\mathrm{X}$ genotype frequency in different goat populations by another authors (TUCKER et al., 1983; BARBANCHO et al., 1984; RODERO et al., 1992; PEPIN and NGUYEN, 1994; OSTERHOFF, 195; SAVIC, 1995; KIM et al., 1997; RODERO et al., 1997). Among all studied populations, phenotype $\mathrm{X}^{+}$had the higher frequency. Only in Spanish Murciana goats, the frequency of $\mathrm{X}^{-}$was higher than $\mathrm{X}^{+}$(BARBANCHO et al., 1984).

However similar tendency in genotype distribution of studied proteins was observed in all analyzed populations, statistically significant differences were found among all races of goats (Table 1).

Table 2

The observed (obs.) and expected (exp.) number of the genotypes of studied blood proteins in different races of goats (Die beobachtete (obs.) und erwartete (exp.) Verteilung der Genotypen der untersuchten Bluteiweißstoffe)

\begin{tabular}{|c|c|c|c|c|c|c|c|c|c|c|c|c|c|c|}
\hline \multirow{2}{*}{ Genotype } & \multirow{2}{*}{$\begin{array}{l}\text { Polish } \\
\text { obs. }\end{array}$} & \multirow{2}{*}{$\begin{array}{l}\text { White } \\
\text { exp. }\end{array}$} & \multicolumn{2}{|c|}{ Czech White } & \multicolumn{2}{|c|}{$\begin{array}{c}\text { Dutch White } \\
\text { I }\end{array}$} & \multicolumn{2}{|c|}{$\begin{array}{c}\text { Dutch White } \\
\text { II }\end{array}$} & \multicolumn{2}{|c|}{ Saanen } & \multicolumn{2}{|c|}{ Alpine } & \multicolumn{2}{|c|}{$\begin{array}{l}\text { Toggen- } \\
\text { burg }\end{array}$} \\
\hline & & & obs. & exp. & obs. & exp. & obs. & exp. & obs. & exp. & obs. & exp. & obs. & exp. \\
\hline Tf AA & 86 & 85.7 & 280 & 280.1 & 43 & 43.2 & 29 & 28.9 & 152 & 152.1 & 55 & 55.0 & 30 & 30.1 \\
\hline Tf $A B$ & 24 & 24.5 & 10 & 9.8 & 7 & 6.5 & 10 & 10.2 & 8 & 7.8 & - & - & 3 & 2.9 \\
\hline Tf BB & 2 & 1.8 & - & 0.1 & - & 0.2 & 1 & 0.9 & - & 0.1 & - & - & - & 0.1 \\
\hline $\mathrm{Hb} \mathrm{AA}$ & 105 & 105.1 & 285 & 285.0 & 39 & 39.6 & 24 & 24.0 & 124 & 122.5 & 33 & 33.4 & 24 & 24.6 \\
\hline $\mathrm{Hb} \mathrm{AB}$ & 7 & 6.8 & 5 & 5.0 & 11 & 9.8 & 14 & 13.9 & 32 & 35.0 & 21 & 18.2 & 9 & 7.8 \\
\hline $\mathrm{Hb} \mathrm{BB}$ & - & 0.1 & - & - & - & 0.6 & 2 & 2.0 & 4 & 2.5 & 1 & 2.4 & - & 0.6 \\
\hline Alb FF & 10 & 2.7 & 1 & 0.1 & 1 & 0.1 & 6 & 2.3 & 20 & 8.6 & 4 & 1.0 & 5 & 1.5 \\
\hline Alb FS & 15 & 29.5 & 7 & 8.9 & 3 & 4.8 & 7 & 14.5 & 34 & 56.9 & 7 & 13.0 & 4 & 11.0 \\
\hline Alb SS & 87 & 79.7 & 282 & 281.1 & 46 & 45.1 & 27 & 23.3 & 106 & 94.6 & 44 & 41.0 & 24 & 20.5 \\
\hline $\mathrm{BX} \mathrm{K}+\mathrm{K}+$ & 70 & 69.9 & 233 & 233.1 & 32 & 32.0 & 21 & 21.0 & 136 & 136.0 & 29 & 29.1 & 33 & 33.0 \\
\hline $\mathrm{BX} \mathrm{K}^{+} \mathrm{k}^{-}$ & 37 & 37.1 & 54 & 53.8 & 16 & 16.0 & 16 & 16.0 & 23 & 23.0 & 22 & 21.8 & - & - \\
\hline BX k- k- & 5 & 4.9 & 3 & 3.1 & 2 & 2.0 & 3 & 3.0 & 1 & 1.0 & 4 & 4.1 & - & - \\
\hline Total & 112 & 112.0 & 290 & 290.0 & 50 & 50.0 & 40 & 40.0 & 160 & 160.0 & 55 & 55.0 & 33 & 33.0 \\
\hline
\end{tabular}

The observed distribution of detected genotypes did not significantly differ from expected distribution in the studied population (Table 2). BARBANCHO et al. (1980) reported the correspondence between expected and observed genotypes distribution of hemoglobin, albumin and transferrin in Spanish goats Murciana, Granadina, Malaguena and Serrana Andaluza. Neither TJANKOV (1972) found statistically significant differences between expected and observed frequencies of transferrin phenotypes in Toggenburg goats, Bulgarian native goats and their crossbreds. However, in crossbreds, he found significantly lower number of observed albumin phenotypes FS and significantly higher number of phenotypes FF and SS than it had been expected. SALERNO et al. (1968) noted opposite situation in goats breed in Lucania (South Italy). There were more heterozygotic albumin phenotypes FS and less 
homozygotic phenotypes FF and SS, than expected. Similar deviation was observed for transferrin.

Table 3 shows the allele frequencies of transferrin, hemoglobin, albumin and protein $\mathrm{X}$ in studied populations of goats. In transferrin, the higher frequency was noted for allele A and it was estimated between 85\% (Dutch White Improved II) and 100\% (Alpine). These results stay in accordance to ones obtained by another authors. Only WATANABE (1971) in Italian Alpine goats and Hungarian Saanen, and BHAT et al. (1982) in goats from India, reported higher frequency of transferrin allele B. In hemoglobin, allel A was present with higher frequency than allele B $(77.5 \%$ in Dutch White Improved II and 99.14\% in Czech White Improved). Other authors noted the same observation - allele A has higher frequency in hemoglobin locus; depending on goat race A frequency changed between $64 \%$ and $100 \%$.

In turn, albumin allele $\mathrm{S}$ had higher frequency $(76.25-98.45 \%)$ than $\mathrm{F}$ one. Such result was confirmed in several goat populations by many authors. In many European, African and Asian goats, the frequency of allele S was 100\% (LIN et al., 1997; NOZAWA et al., 1978; PEPIN and NGUYEN, 1994; OSTERHOFF, 1995). Only in Italian and Japan Saanen, native Japan goats (WATANABE, 1971) and Spanish Serrana Andaluza (BARBANCHO et al., 1980), albumin allele F was more frequent.

Table 3

The frequency of transferrin, hemoglobin, albumin and protein $\mathrm{X}$ alleles in studied populations of goats (Frequenz der Allele Transferrin, Hämglobin, Albumin und Eiwei $\beta$ X in den untersuchten Ziegenpopulationen)

\begin{tabular}{|c|c|c|c|c|c|c|c|}
\hline Allele & $\begin{array}{c}\text { Polish White } \\
\mathrm{n}=112 \\
{[\%]}\end{array}$ & $\begin{array}{c}\text { Czech White } \\
\mathrm{n}=290 \\
{[\%]}\end{array}$ & $\begin{array}{c}\text { Dutch White I } \\
\mathrm{n}=50 \\
{[\%]}\end{array}$ & $\begin{array}{c}\text { Dutch White II } \\
\mathrm{n}=40 \\
{[\%]}\end{array}$ & $\begin{array}{c}\text { Saanen } \\
\mathrm{n}=160 \\
{[\%]}\end{array}$ & $\begin{array}{c}\text { Alpine } \\
\mathrm{n}=55 \\
{[\%]}\end{array}$ & $\begin{array}{c}\text { Toggenburg } \\
\mathrm{n}=33 \\
{[\%]}\end{array}$ \\
\hline Tf A & 87.50ADE & $98.28 \mathrm{ABC}$ & $93.00 \mathrm{BH}$ & 85.00CFGa & $97.50 \mathrm{DF}$ & 100.00EGH & \\
\hline Tf B & 12.50 & 1.72 & 7.00 & 15.00 & 2.50 & 0.00 & 4.55 \\
\hline $\mathrm{HbA}$ & $96.88^{\text {FGHIab }}$ & $99.14^{\mathrm{ABCDEa}}$ & $89.00^{\mathrm{Abcd}}$ & $77.50^{\mathrm{BFce}}$ & $87.50^{\mathrm{CGef}}$ & $79.09^{\mathrm{DHdf}}$ & $86.36^{\mathrm{EI}}$ \\
\hline $\mathrm{HbB}$ & 3.13 & 0.86 & 11.00 & 22.50 & 12.50 & 20.91 & 13.64 \\
\hline $\mathrm{Al} \mathrm{F}$ & $15.63^{\mathrm{AFa}}$ & $1.55^{\mathrm{ABCDE}}$ & $5.00^{\text {FGHIbc }}$ & $23.75^{\mathrm{BG}}$ & $23.13^{\mathrm{CHab}}$ & $13.64^{\mathrm{Dc}}$ & $21.21^{\mathrm{EI}}$ \\
\hline $\mathrm{Al} \mathrm{S}$ & 84.38 & 98.45 & 95.00 & 76.25 & 76.88 & 86.36 & 78.79 \\
\hline $\mathrm{BX} \mathrm{K}^{+}$ & $79.02^{\mathrm{AFG}}$ & $89.66^{\mathrm{ABCDE}}$ & $80.00^{\mathrm{BHI}}$ & $72.50^{\mathrm{CJK}}$ & $92.19^{\text {FHJLN }}$ & $72.37^{\text {DLEM }}$ & $100.00^{\text {EGIKŁMN }}$ \\
\hline $\mathrm{BX} \mathrm{k}^{-}$ & 20.98 & 10.34 & 20.00 & 27.50 & 7.81 & 27.27 & 0.00 \\
\hline
\end{tabular}

The frequencies, showed in lines marked with identical letter, differ significantly. Small letters indicate the significance of differences at $\mathrm{P} \leq$ 0.05 ; big letters - at $\mathrm{P} \leq 0.01$.

In protein $\mathrm{X}$ locus, allele $\mathrm{K}^{+}$was definitely more frequent. Its frequency was the highest in Toggenburg goats $(100 \%)$ and the lowest in Alpine goats $(72.37 \%)$. Although only few authors reported the frequency of protein $\mathrm{X}$ alleles, most of them obtained identical results (SAVIC, 1995; KIM et al., 1997; RODERO et al., 1997). Only in Spanish Andalusian Black goats, allele $\mathrm{k}^{-}$had a little higher frequency $(50.6 \%)$ (RODERO et al., 1997).

Statistically significant differences were found between the frequencies of studied proteins alleles in all analyzed goat populations (Table 2).

Considering the frequency of homo- and heterozygotes in studied protein loci, more homozygotic genotypes were found in tested goats populations (Table 3 ). However, all populations statistically significantly differed in the level of homo- and heterozygosisty. In transferrin locus, Alpine goats showed the higher homozygosity $(100 \%)$ and Dutch White Improved II - the lowest (75\%). The homozygosity of hemoglobin genotypes changed from $65 \%$ in Dutch White Improved II to $98.3 \%$ in 
Czech White Improved. Also albumin genotypes were the least homozygotic in Dutch White Improved II (82.5\%) and the most - in Czech White Improved (97.6\%). The lowest homozygosity of protein X genotypes was noted in Dutch White Improved II and Alpine (60\%) when the highest was found in Toggenburg goats $-100 \%$ of the population. The coefficient of mean heterozygosity, estimated basing on the results obtained for each protein locus, had the lowest value in Czech White Improved (0.0655) and the highest - in Dutch White Improved II (0.2938) (Table 4).

Table 4

The frequency of homo- and heterozygotic genotypes of transferrin, hemoglobin, albumin and protein $\mathrm{X}$ in studied populations of goats (Frequenz der homo- und heterozygotischen GenotypenTransferrin, Hämglobin, Albumin und Eiwei $\beta$ X in den untersuchten Ziegenpopulationen)

\begin{tabular}{|c|c|c|c|c|c|c|c|}
\hline Protein Genotype & $\begin{array}{c}\mathrm{n}=112 \\
{[\%]}\end{array}$ & $\begin{array}{c}\mathrm{n}=290 \\
{[\%]}\end{array}$ & $\begin{array}{c}\text { Dutch } \\
\text { White } \\
\mathrm{n}=50 \\
{[\%]}\end{array}$ & $\begin{array}{c}\text { Dutch } \\
\text { White } \\
n=40 \\
{[\%]}\end{array}$ & $\begin{array}{c}\mathrm{n}=160 \\
{[\%]}\end{array}$ & $\begin{array}{c}\mathrm{n}=55 \\
{[\%]}\end{array}$ & Toggenburg \\
\hline Tf homozygotic & $78.6^{\mathrm{AEF}}$ & $96.6^{\mathrm{ABCD}}$ & $86.0^{\mathrm{BI}}$ & $75.0^{\mathrm{CGH}}$ & $95.0^{\mathrm{DEG}}$ & $100.0^{\mathrm{FHI}}$ & 90.9 \\
\hline Tf heterozygotic & 21.4 & 3.4 & 14.0 & 25.0 & 5.0 & 0.0 & 9.1 \\
\hline Hb homozygotic & $93.8^{\text {FGHIJa }}$ & $98.3^{\mathrm{ABCDEa}}$ & $78.0^{\mathrm{AF}}$ & $65.0^{\mathrm{BGb}}$ & $80.0^{\mathrm{CHKb}}$ & $61.8^{\text {DIK }}$ & $72.7^{\mathrm{EJ}}$ \\
\hline Hb heterozygotic & 6.3 & 1.7 & 22.0 & 35.0 & 20.0 & 38.2 & 27.3 \\
\hline Al homozygotic & $86.6^{\mathrm{A}}$ & $97.6^{\mathrm{ABCDE}}$ & $94.0^{\mathrm{F}}$ & $82.5^{\mathrm{B}}$ & $78.8^{\mathrm{CF}}$ & $87.3^{\mathrm{D}}$ & $87.9^{\mathrm{E}}$ \\
\hline Al heterozygotic & 13.4 & 2.4 & 6.0 & 17.5 & 21.3 & 12.7 & 12.1 \\
\hline BX homozygotic & $67.0^{\mathrm{ADE}}$ & $81.4^{\mathrm{ABCa}}$ & $68.0^{\mathrm{FGa}}$ & $60.0^{\mathrm{BHI}}$ & $85.6^{\text {DFHJb }}$ & $60.0^{\mathrm{JK}}$ & $100.0^{\text {CEGIKb }}$ \\
\hline BX heterozygotic & 33.0 & 18.6 & 32.0 & 40.0 & 14.4 & 40.0 & 0.0 \\
\hline $\begin{array}{l}\text { The coefficient of } \\
\text { mean homozygosity }\end{array}$ & 3.2589 & 3.7379 & 3.2600 & 2.8250 & 3.3938 & 3.0909 & 3.5152 \\
\hline
\end{tabular}

Table 5

The observed (obs.) and expected (exp.) number of homo- and heterozygotic genotypes of transferrin, hemoglobin, albumin and protein $\mathrm{X}$ in different goat races (Die beobachtete (obs.) und erwartete (exp.) Verteilung der homo- und heterozygotischen Genotypen Transferrin, Hämglobin, Albumin und Eiwei $\beta$ X in den untersuchten Ziegenpopulationen)

\begin{tabular}{|c|c|c|c|c|c|c|c|c|c|}
\hline \multirow{2}{*}{ Race } & \multirow{2}{*}{$\begin{array}{l}\text { Popu- } \\
\text { lation - } \\
\text { size }\end{array}$} & \multicolumn{2}{|c|}{ Transferrin } & \multicolumn{2}{|c|}{ Hemoglobin } & \multicolumn{2}{|c|}{ Albumin } & \multicolumn{2}{|c|}{ Protein $X$} \\
\hline & & $\begin{array}{c}\text { Homo- } \\
\text { zygotes } \\
\text { obs./exp. }\end{array}$ & $\begin{array}{l}\text { Hetero- } \\
\text { zygotes } \\
\text { obs./exp. }\end{array}$ & $\begin{array}{c}\text { Homo- } \\
\text { zygotes } \\
\text { obs./exp. }\end{array}$ & $\begin{array}{l}\text { Hetero- } \\
\text { zygotes } \\
\text { obs./exp. }\end{array}$ & $\begin{array}{c}\text { Homo- } \\
\text { zygotes } \\
\text { obs./exp. }\end{array}$ & $\begin{array}{l}\text { Hetero- } \\
\text { zygotes } \\
\text { obs./exp. }\end{array}$ & $\begin{array}{c}\text { Homo- } \\
\text { zygotes } \\
\text { obs./exp. }\end{array}$ & $\begin{array}{l}\text { Hetero- } \\
\text { zygotes } \\
\text { obs./exp. }\end{array}$ \\
\hline Polish White & 112 & $88 / 87.5$ & $24 / 24.5$ & $105 / 105.2$ & $7 / 6.8$ & $97 / 82.5$ & $15 / 29.5^{* *}$ & $75 / 74.9$ & $37 / 37.1$ \\
\hline Czech White & 290 & $280 / 280.2$ & $10 / 9.8$ & $285 / 285.0$ & $5 / 5.5$ & $283 / 281.1$ & $7 / 8.9$ & $236 / 236.2$ & $54 / 53.8$ \\
\hline Dutch White I & 50 & $43 / 43.5$ & $7 / 6.5$ & $39 / 40.2$ & $11 / 9.8$ & $47 / 45.2$ & $3 / 4.8$ & $34 / 34.0$ & $16 / 16.0$ \\
\hline Dutch White II & 40 & $30 / 29.8$ & $10 / 10.2$ & $26 / 26.0$ & $14 / 13.9$ & $33 / 25.5$ & $7 / 14.5^{* *}$ & $24 / 21.1$ & $16 / 16.0$ \\
\hline Saanen & 160 & $152 / 152.2$ & $8 / 7.8$ & $128 / 125.0$ & $32 / 35.0$ & $126 / 103.1$ & $34 / 56.9^{* *}$ & $137 / 137.0$ & $23 / 23.0$ \\
\hline Alpine & 55 & $55 / 55.0$ & $0 / 0.0$ & $34 / 36.8$ & $21 / 18.2$ & $48 / 42.0$ & $7 / 13.0$ & $33 / 33.2$ & $22 / 21.8$ \\
\hline Toggenburg & 33 & $30 / 30.1$ & $3 / 2.9$ & $24 / 25.2$ & $9 / 7.8$ & $29 / 22.0$ & $4 / 11.0^{* *}$ & $33 / 33.0$ & $0 / 0.0$ \\
\hline
\end{tabular}

** - differences significant at $\mathrm{P} \leq 0.01$

The distribution of homo- and heterozygotes observed in transferrin, hemoglobin and protein X loci stayed in accordance with the expected one. Only in four racial goats populations, deviation of genetic balance in albumin locus was noted. In the herd of Polish White Improved, Dutch White Improved II, Saanen and Toggenburg goats, there were significantly less heterozygotic albumin genotypes than it was expected (Table 5). RODERO et al. [1992], studying the polymorphism in transferrin, hemoglobin and albumin loci in goats of few populations of Negra Serrana, reported 
significantly higher number of observed heterozygotic hemoglobin genotypes than expected one. In transferrin and hemoglobin loci the situation was opposite - there were less heterozygotic genotypes observed than expected. In 1997, RODERO et al. noted no statistically significant divergence from Hardy-Weinberg's low in the distribution of transferrin and hemoglobin homo- and heterozygosity in Andalusian White and Andalusian Black goats, while heterozygotic genotypes of albumin were less observed than expected.

Table 6. shows the frequency of hemotypes. Among studied goats populations, 18 hemotypes of 54 possible were present. The smallest number of different hemotypes was noted in Czech White Improved (6) and the largest - in Dutch White Improved (16). Among that second herd, also the largest number of rare hemotypes was found (9). By "rare hemotype" we mean the hemotype that appeared only in one animal in given herd. In all tested population, homozygotic hemotype TfAA/HbAA/AlbSS/BXK ${ }^{+} \mathrm{K}^{+}$had the highest frequency. However, statistically significant differences were found in the frequencies of different hemotypes between each studied races (Table 6).

Table 6

The frequency of hemotypes $(\mathrm{Tf} / \mathrm{Hb} / \mathrm{Alb} / \mathrm{BX})$ in studied races of goats (Frequenz der Hämotypen $(\mathrm{Tf} / \mathrm{Hb} /$ $\mathrm{Alb} / \mathrm{BX})$ in den untersuchten Ziegenrassen)

\begin{tabular}{|c|c|c|c|c|c|c|c|c|c|}
\hline & $\begin{array}{c}\text { Hemotype } \\
\text { (Tf/Hb/Alb/BX) }\end{array}$ & $\begin{array}{c}\text { Polish } \\
\text { White } \\
{[\%]}\end{array}$ & $\begin{array}{c}\text { Czech } \\
\text { White } \\
{[\%]}\end{array}$ & $\begin{array}{c}\text { Dutch } \\
\text { White I } \\
{[\%]}\end{array}$ & $\begin{array}{c}\text { Dutch } \\
\text { White II } \\
{[\%]}\end{array}$ & $\begin{array}{c}\text { Saanen } \\
{[\%]}\end{array}$ & $\begin{array}{c}\text { Alpine } \\
{[\%]}\end{array}$ & $\begin{array}{c}\text { Toggen- } \\
\text { burg } \\
{[\%]}\end{array}$ & $\begin{array}{c}\text { Total } \\
{[\%]}\end{array}$ \\
\hline 1. & $\mathrm{AA} / \mathrm{AA} / \mathrm{FF} / \mathrm{K}^{+}-$ & $4.46^{\mathrm{A}}$ & $0.35^{\mathrm{ABCD}}$ & $2.00^{\mathrm{B}}$ & 7.50 & $8.75^{\mathrm{C}}$ & 1.82 & $12.12^{\mathrm{D}}$ & 3.92 \\
\hline 2. & $\mathrm{AA} / \mathrm{AA} / \mathrm{FS} / \mathrm{K}^{+}-$ & $8.04^{\mathrm{ab}}$ & $2.41^{\mathrm{Aa}}$ & 6.00 & 5.00 & $16.25^{\mathrm{ABb}}$ & $3.64^{\mathrm{B}}$ & 9.09 & 7.03 \\
\hline 3. & $\mathrm{AA} / \mathrm{AA} / \mathrm{FS} / \mathrm{k}^{-} \mathrm{k}^{-}$ & 0.00 & $0.00^{\mathrm{a}}$ & 0.00 & 0.00 & 0.00 & $3.64^{\mathrm{a}}$ & 0.00 & 0.27 \\
\hline 4. & $\mathrm{AA} / \mathrm{AA} / \mathrm{SS} / \mathrm{K}^{+}-$ & $57.14^{\mathrm{Aa}}$ & $91.03^{\text {abcdef }}$ & $56.00^{\mathrm{Bb}}$ & $27.50^{\mathrm{ABcgh}}$ & $47.50^{\mathrm{dg}}$ & $47.27^{\mathrm{eh}}$ & $45.46^{\mathrm{f}}$ & 65.40 \\
\hline 5. & $\mathrm{AA} / \mathrm{AA} / \mathrm{SS} / \mathrm{k}^{-} \mathrm{k}^{-}$ & $4.46^{\mathrm{a}}$ & 1.03 & 4.00 & 2.50 & $0.00^{\mathrm{a}}$ & 3.64 & 0.00 & 1.76 \\
\hline 6. & $\mathrm{AA} / \mathrm{AB} / \mathrm{FF} / \mathrm{K}^{+}-$ & 0.0 & $0.00^{\mathrm{ab}}$ & 0.00 & 2.50 & $2.50^{\mathrm{a}}$ & $5.45^{\mathrm{b}}$ & 3.03 & 1.22 \\
\hline 7. & $\mathrm{AA} / \mathrm{AB} / \mathrm{FS} / \mathrm{K}^{+}-$ & 0.89 & $0.00^{\mathrm{ABC}}$ & 0.00 & $5.00^{\mathrm{A}}$ & $5.00^{\mathrm{B}}$ & $5.45^{\mathrm{C}}$ & 3.03 & 2.03 \\
\hline 8. & $\mathrm{AA} / \mathrm{AB} / \mathrm{SS} / \mathrm{K}^{+}-$ & $1.79^{\mathrm{FGHIJ}}$ & $1.73^{\mathrm{ABCDE}}$ & $18.00^{\mathrm{AF}}$ & $17.50^{\mathrm{BG}}$ & $12.50^{\mathrm{CHK}}$ & $27.27^{\mathrm{DIK}}$ & $18.18^{\mathrm{EJ}}$ & 8.65 \\
\hline 9. & $\mathrm{AA} / \mathrm{BB} / \mathrm{FS} / \mathrm{k}^{-} \mathrm{k}^{-}$ & 0.00 & 0.00 & 0.00 & 2.50 & 0.00 & 0.00 & 0.00 & 0.13 \\
\hline 10. & $\mathrm{AA} / \mathrm{BB} / \mathrm{SS} / \mathrm{K}^{+}-$ & 0.00 & $0.00^{\mathrm{a}}$ & 0.00 & 2.50 & $2.50^{\mathrm{a}}$ & 1.82 & 0.00 & 0.81 \\
\hline 11. & $\mathrm{AB} / \mathrm{AA} / \mathrm{FF} / \mathrm{K}^{+}-$ & $4.46^{\mathrm{A}}$ & $0.00^{\mathrm{A}}$ & 0.00 & 2.50 & 1.25 & 0.00 & 0.00 & 1.08 \\
\hline 12. & $\mathrm{AB} / \mathrm{AA} / \mathrm{FS} / \mathrm{K}^{+}-$ & $4.46^{\mathrm{Aac}}$ & $0.00^{\mathrm{A}}$ & 0.00 & 2.50 & $0.00^{\mathrm{a}}$ & 0.00 & 0.00 & 0.81 \\
\hline 13. & $\mathrm{AB} / \mathrm{AA} / \mathrm{SS} / \mathrm{K}^{+}-$ & $8.93^{\mathrm{abc}}$ & $3.45^{\mathrm{a}}$ & $10.00^{\mathrm{d}}$ & 7.50 & $3.12^{\mathrm{b}}$ & $0.00^{\mathrm{cd}}$ & 6.06 & 4.73 \\
\hline 14. & $\mathrm{AB} / \mathrm{AA} / \mathrm{SS} / \mathrm{k}^{-} \mathrm{k}^{-}$ & 0.00 & 0.00 & 0.00 & 2.50 & 0.63 & 0.00 & 0.00 & 0.27 \\
\hline 15. & $\mathrm{AB} / \mathrm{AB} / \mathrm{FS} / \mathrm{K}^{+}-$ & 0.89 & 0.00 & 0.00 & 2.50 & 0.00 & 0.00 & 0.00 & 0.27 \\
\hline 16. & $\mathrm{AB} / \mathrm{AB} / \mathrm{SS} / \mathrm{K}^{+}-$ & $2.68^{\mathrm{a}}$ & $0.00^{\mathrm{ABa}}$ & $4.00^{\mathrm{A}}$ & $7.50^{\mathrm{BC}}$ & $0.00^{\mathrm{C}}$ & 0.00 & 3.03 & 1.22 \\
\hline 17. & $\mathrm{BB} / \mathrm{AA} / \mathrm{FF} / \mathrm{K}^{+}-$ & 0.00 & 0.00 & 0.00 & 2.50 & 0.00 & 0.00 & 0.00 & 0.18 \\
\hline 18. & $\mathrm{BB} / \mathrm{AA} / \mathrm{SS} / \mathrm{K}^{+}-$ & 1.79 & 0.00 & 0.00 & 0.00 & 0.00 & 0.00 & 0.00 & 0.27 \\
\hline & Total & 100.0 & 100.0 & 100.0 & 100.0 & 100.0 & 100.0 & 100.0 & 100.0 \\
\hline
\end{tabular}

The frequencies, showed in lines marked with identical letter, differ significantly. Small letters indicate the significance of differences at $\mathrm{P} \leq$ 0.05 ; big letters - at $\mathrm{P} \leq 0.01$.

The level of genetic consolidation was estimated basing on the frequency of hemotypes (Table 7). Genetic consolidation is higher when the level of genetic differentiation is higher in the population. The highest value of that level was estimated in Czech White Improved (48.33) and the lowest one in Dutch White Improved II (2.5). Also index of population genetic differentiation and index of hemotype differentiation showed that Czech White Improved population was the most, and Dutch White Improved one was the least consolidated. Higher values of both indexes mean the highest differentiation in given population. The more frequent 
hemotype: TfAA/HbAA/AlbSS/BXK ${ }^{+} \mathrm{K}^{+}$had also the highest frequency in Czech White goats $(91,03 \%)$ and the lowest - in Dutch White II herd (27.50\%).

Table 7

The genetic consolidation of populations of studied goats (Die genetische Konsolidierung von untersuchten Ziegenpopulationen)

\begin{tabular}{lccccccc}
\hline \multicolumn{1}{c}{ Race } & $\begin{array}{c}\text { Popula- } \\
\text { tion size }\end{array}$ & $\begin{array}{c}\text { Number } \\
\text { of hemo- } \\
\text { types }\end{array}$ & $\begin{array}{c}\text { Number } \\
\text { of rare } \\
\text { hemo- } \\
\text { types }\end{array}$ & $\begin{array}{c}\text { The level } \\
\text { of genetic } \\
\text { different- } \\
\text { tiation }\end{array}$ & $\begin{array}{c}\text { Index of } \\
\text { population } \\
\text { different- } \\
\text { tiation }\end{array}$ & $\begin{array}{c}\text { Index if } \\
\text { hemotype } \\
\text { different- } \\
\text { tiation }\end{array}$ & $\begin{array}{c}* \text { The } \\
\text { frequency } \\
\text { of more } \\
\text { frequent } \\
\text { hemotype } \\
{[\%]}\end{array}$ \\
\hline Polish White & 112 & 12 & 2 & 9.33 & 1.79 & 16.67 & 57.14 \\
Czech White & 290 & 6 & 1 & 48.33 & 0.34 & 16.67 & 91.03 \\
Dutch White I & 50 & 7 & 1 & 7.14 & 2.00 & 14.29 & 56.00 \\
Dutch White II & 40 & 16 & 9 & 2.50 & 22.50 & 56.25 & 27.50 \\
Saanen & 160 & 10 & 1 & 16 & 0.63 & 10.00 & 47.50 \\
Alpine & 55 & 9 & 2 & 6.11 & 3.64 & 22.22 & 47.27 \\
Toggenburg & 33 & 8 & 3 & 4.125 & 9.09 & 37.50 & 45.46 \\
\hline
\end{tabular}

*The more frequent hemotype TfAA/HbAA/AlSS/BXK ${ }^{+}$

Table 8 shows the genetic distance between studied populations of goats, which was estimated according to the frequency of alleles of tested proteins. The largest genetic distance was noted between Czech White Improved and Dutch White Improved II $(0.03092)$ while the smallest - between Saanen and Toggenburg goats $(0.00200)$.

Table 8

The genetic distance between studied goat populations (Die genetische Distanz zwischen untersuchten Ziegenpopulationen)

\begin{tabular}{lcccccc}
\hline \multicolumn{1}{c}{ Rasa } & Czech White & Polish White & $\begin{array}{c}\text { Dutch White } \\
\text { I }\end{array}$ & $\begin{array}{c}\text { Dutch White } \\
\text { II }\end{array}$ & Saanen & Alpine \\
\hline Polish White & 0.00875 & & & & & \\
Dutch White I & 0.00446 & 0.00626 & & & & \\
Dutch White II & 0.03092 & 0.01353 & 0.01508 & & & \\
Saanen & 0.01502 & 0.01308 & 0.01550 & 0.01699 & & \\
Alpine & 0.01974 & 0.01679 & 0.00814 & 0.00918 & 0.01707 & \\
Toggenburg & 0.01745 & 0.01958 & 0.02060 & 0.02525 & 0.00200 & 0.02665 \\
\hline
\end{tabular}

Many authors analyzed genetic distance between several populations of goats from different geographic regions of the world. RODERO et al. [1992] estimated that distance (according to NEI method) between different populations of Negra Serrana; its value hesitated from 0.0062 to 0.0093 . NOZAWA et al. [1978] noted the genetic distance between few Japan native goats and Japan Saanen, which was 0.0004 0.0023 between native races and $0.0046-0.0088$ between native and Saanen. HARTL et al. [1990] provided very interesting study on genetic distance between wild goats, domestic goats, ibex, sheep and antelopes. They reported the smallest distance between wild and domestic goats (0.0062) and the largest between antelopes Nigali and chamois (1.0641).

PEPIN and NGUYEN [1994] studied the genetic distance between French Alpine and Saanen goats and goats from Guadalupe, New Guinea and West Africa. They used four different methods of: CAVALLI-SFORZA and BODMER [1971], GEORGIUS [1984], BALAKRISHNAN and SANGHVI [1968] and NEI [1972]. The distance was estimated basing on the polymorphism of transferrin, hemoglobin, albumin, protein X, carbonic anhydrase and six blood group systems. All four methods showed that the 
smallest genetic distance characterized Alpine and Saanen goats (0.0160; according to Nei method) and the largest - Saanen and goats from Sahel in West Africa (0.1530; Nei). The distance between European and African races was $2-4$ times larger than that between goats from the same geographic region.

RODERO et al. [1997] also estimated the genetic distance between Andalusian White and Andalusian Black goats, studying the polymorphism of transferrin, hemoglobin, albumin, protein $\mathrm{X}$, catalase, and potassium level, using Cavalli-Sforza method. That distance had a value of 0.1180 .

\section{Conclusions}

Basing on electrophoretic separation of proteins, two different alleles, encoded three different genotypes were found in the locus of transferrin, hemoglobin, albumin and protein $\mathrm{X}$. The distribution of each genotype observed in studied goats populations corresponded with the expected one.

The larger number of homozygotic than heterozygotic genotypes in four studied loci was noted in each racial population. The coefficient of mean heterozygosity in all four proteins loci had the lowest value in Czech White Improved population (0.0655) and the highest in Dutch White Improved II (0.2938).

Statistically significant differences were found in the frequency of alleles and genotypes of each studied protein between all experimental goats populations.

Among studied goats populations, 18 hemotypes of 54 possible were found. Basing on the frequency of hemotypes, the level of genetic consolidation was established. The herd of Dutch White Improved II goats was the most differentiated while Czech White Improved - the least.

The largest genetic distance, estimated from the frequency of transferrin, hemoglobin, albumin and protein X alleles, was found between Dutch White Improved II and Czech White Improved (0.03092). The smallest genetic distance characterized Saanen and Toggenburg goats 90.00200).

\section{References}

BALAKRISHNAN, V.; SANGHVI, L.D.:

Distance between populations on the basis of attribute data. Biometrics 24 (1968), 859-865

BARBANCHO, M.; LLANES, D.; MORERA, L.; ARZON, R.; RODERO, A.:

Biochemical polymorphisms in Spanish goat breeds. I. Murciana, Granadina, Malaguena and Serrana Andaluza. Archivos de Zootecnia 29 (1980), 215-259

BARBANCHO,M.; LLANES, D.; MORERA, L.; GARZON, R.; RODERO, A.:

Genetic markers in the blood of Spanish goat breeds. Anim. Blood Grps. and Biochem. Genetics 15 (1984), 207-212

BHAT, P.P.; SANTIAGO, T.C.; SINHA, N.K.:

Blood potassium, sodium, haemoglobin and transferrin polymorphism in Jumanapari and Barbari goats. Indian J. Anim. Sci. 53 (1983) 10, 1151-1152

CAVALLI-SFORZA, L.L.; BODMER, W.F.:

Human evolution. The genetics of the human population. W.H. Freeman, San Francisco, 1971

EFREMOV, G.; BRAEND, M.:

Haemoglobins, transferrins, albumins of sheep and goats. In: Proc. IXth Eur. Anim. Blood Grps. and Biochem. Polymorphism, Prague, 1964, 313-320

GARCIA-CASAS, C.; MORENO, A.; CAPOTE, J.; DE LA HABA, M.R.:

Characterization of the Canary racial goat groups with erythrocyte genetics markers. Small Ruminant Research 7 (1992), 361-368

GREGORIUS, H.R.:

A unique genetic dystance. Biometrical J. 26 (1984), 8-13 
HARTL, G.B.; BURGER, H.; WILLING, R.; SUCHENTRUNK, F.:

On the biochemical systematics of the Caprini and the Rupicaprini. Bioch. Syst. Ecol. 18 (1990) 2/3, $175-182$

HUISMAN, T.H.J.; VAN DER VLIET, G.; SEBUS, T.:

Sheep hemoglobins. Some genetic and physiological aspects of two differerent adult hemoglobins in sheep. Nature 182 (1958), 67-73

KAMIŃSKI, M.:

Genetic diversity in horses inferred from distribution of hemotypes. II. Genetic structure of mixed breed

KAMIŃSKI, M. population. Comp. Bioch. Physiol. B 79 (1984) 1, 61-66

Genetic structure of populations of horses based on distribution of hemotypes. Bioch. Syst. Ecol. 10 (1982) 4, 377-385

KATSUMATA, M.; NOZAWA, K.; AMANO, T.; SHINGO, A.; ABE, T.:

Blood protein gene constitution of the Japonesse Saanenbreed of goat. Jpn. J. Zootech. Sci. 52 (1981), 553-561

KIM, G.W.; LEE, I.H.; CHO, K.S.; CHUNG, J.R.; YOO, J.Y.; YOON, J.M.; LEE, J.Y.; PARK, H.Y.:

Analysis of genetic polymorphisms of red cell X-protein and haemoglobin loci in Korean native goats. Korean J. Anim. Sci. 39 (1997) 6, 661-668

LIN, H.J.; LUO, Y.Z.; HAN, J.L.; LUO, Y.Z.:

Polymorphism of serum proteins and amylase in crossbreds of Angora x Zhongwei goats. Anim. Biotech. Biulletin 5 (1996) 10, 89-91

NEI, M.; ROYCHOUDHURY, K.:

NEI, M.:

Sampling variances of heterozygosity and genetic distance. Genetics 76 (1974), 379-390

Genetic distance between populations. American Naturalist 106 (1972), 92-283

NOZAWA, K.; SHINJO, A.; SHOTAKE, T.:

Population genetics of farm animals. III. Blood-protein variations in the meat goats in Okinawa Islands of Japan. Zeitschrift für Tierzüchtung und Züchtungsbiologie 95 (1978) 1, 60-77

OSTERHOFF, D.R.; WARD-COX, I.S.:

Serum polimorphism in three Suoth African goat breeds. Proc. $12^{\text {th }}$ Eur. Conf. Anim. Blood Grps Bioch. Polymorphism, Budapest 1972, 579-582

OSTERHOFF, D.R.:

Studies on blood groups and biochemical polymorphisms in goats. Arch. Tierz., Dummerstorf 38 (1995) $5,553-561$

PEPIN, L.; NGUYEN, T.C.:

Blood groups and protein polymorphisms in five goats breeds (Capra circus). Anim. Genet. 25 (1994), 333-336

PEPIN, L.; NGUYEN, T.C.:

Blood groups and protein polymorphism in five goats breeds (Capra hircus). Anim. Genet. 25 (1994), 333-336

RODERO, E.; HABA DE LA, M.R.; RODERO, A.:

Genetic study of Andalusia's ovine and caprine breeds. J. Anim. Breed. Genet. 114 (1997), 143-161

RODERO, E.; HABA DE LA, M.R.; RODERO, A.:

Genetic study of Andalusia's ovine and caprine breeds. J. Anim. Breed. Genet. 114 (1997), 143-161

RODERO, S.E.; HABA GIRALDO DE LA, M.R.; ZAMORANO SERRANO, M.J.; RODERO

FRANGANILLO, A.; GONZALEZ MARTINEZ, A.:

Study of the genetic variability of the Negra Serrana goat breed. Arch. Zootec. 41 (1992), 537-542

RODERO, S.E.; HABA GIRALDO DE LA, M.R.; ZAMORANO SERRANO, M.J.; RODERO

FRANGANILLO, A.; GONZALEZ MARTINEZ, A.:

Study of the genetic variability of the Negra Serrana goat breed. Arch. Zootec. 41 (1992), 537-542

SALERNO, A.; MARONE, L.; IORIO, M.:

Genetic studies on the haemoglobin, transferrin, albumin and malate dehydrogenase variants in a goat population bred in southern Italy. Genet. Agr. 31 (1977), 369-379

SALERNO, A.; MONTEMURRO, N.; L'AFFLITTO, A.:

Research on protein polymorphism in a goat population of south Italy. Xith European Conference on Animal Blood Groups and Bochemical polymorphism, Warsaw, July $2^{\text {nd }}-6^{\text {th }}, 517-520,1968$

SAVIC, M.; JOVANOVIC, S.; TRAILOVIC, R.:

Some genetic markers in the blood of the Balkan goat. Acta Vet. Beograd 455 (1995) 6, 299-302

SERRANO, I.; CAPOTE, J.; CASAS, C.; ZARO, N.; DELGADO, J.V.; MORENO, A.:

Ethnologic characterization of Canary goat group. 40th Annual Meeting of the EAAP. II, 171-172, 1989

TJANKOV, S.: 
Polymorphism of some serum protein systems in goats. XIIth European Conference on Animal Blood Groups Biochemical Polymorphism Budapest, 575-578, 1972

TUCKER, E.M.; CLARKE, S.W.; OSTERHOFF,D.R.;GROENEWALD J.:

An investigation of five genetic loci controlling polimorphic variants in the red cells of goats. Anim. Blood Grps. Bioch. Genet. 14 (1983), 269-277

TUCKER, E.M.; DENIS, B.; KILGOUR, L.:

Blood genetic marker studies of a sheep-goat hybrid and its back-cross offspring. Anim. Genet. 20 (1989), 179-186

VANKAN, D.M.; BELL, K.:

A new transferrin allele in Australian goats. Anim. Genet. 23 (1992), 453-456

WATANABE, S.:

Studies on the polymorphism in serum protein of goats. Memoirs of the Tokio University of Agriculture XIV, March 27-69, 1971

Received: 2000-10-09

Accepted: 2002-03-01

Author's address

Dr. KATARZYNA WOJDAK-MAKSYMIEC

Department of Genetics and Animal Breeding

Agricultural University of Szczecin

ul. Doktora Judyma 6

71-460 Szczecin

Poland

Tel./fax: (091) 4541497 ,

E-Mail: kasia@ar.zsi.pl 